\title{
A Proposal for Geography Competence Assessment in Geography Fieldtrips for Sustainable Education
}

\author{
Alfonso García de la Vega (D)
}

check for updates

Citation: García de la Vega, A. A Proposal for Geography Competence Assessment in Geography Fieldtrips for Sustainable Education.

Sustainability 2022, 14, 1429. https:// doi.org/10.3390/su14031429

Academic Editor: Pedro Guilherme Rocha dos Reis

Received: 5 November 2021

Accepted: 20 January 2022

Published: 26 January 2022

Publisher's Note: MDPI stays neutral with regard to jurisdictional claims in published maps and institutional affiliations.

Copyright: (C) 2022 by the author. Licensee MDPI, Basel, Switzerland. This article is an open access article distributed under the terms and conditions of the Creative Commons Attribution (CC BY) license (https:// creativecommons.org/licenses/by/ $4.0 /)$.
Facultad de Formación de Profesorado y Educación, Universidad Autónoma de Madrid, 28049 Madrid, Spain; alfonso.delavega@uam.es

\begin{abstract}
The geography fieldtrip is a well-consolidated learning mode, but may become a procedural teaching strategy in geography. In geographical education, fieldtrips foster students' overall knowledge-building processes to become world citizens, and thus to be fully committed to the Earth's sustainability. Fieldtrips prepare students for applying and connecting knowledge in a real context. However, the geography fieldtrip may lack robust proposals on challenges and achievements that are clearly identified as assessable geographical geoabilities for competences. This paper offers a geography competence-oriented fieldtrip assessment framework. Project-based learning is chosen as the didactic approach, in which the fieldtrip project is built upon a real-world acute question of the students' interest and choice, and solutions are reached following the enquiry learning method. The proposal brings cognitive domain (geographical thinking) and process (geospatial thinking) into alignment with geography and cross-cutting competences, corresponding geoabilities and geoskills, and learning outcomes in geography fieldtrips. The framework provides an assessment procedure (learning outcomes, tasks, and evidence) and tools (rubrics of evidence for learning outcomes) for fieldtrip geoskill assessment.
\end{abstract}

Keywords: geography fieldtrip; geography competence; cross-cutting competences; geoabilities; geoskills; learning outcomes; assessment evidence; sustainable education

\section{Introduction}

This paper aims to provide a teaching framework for assessing geography competence in the context of geography fieldtrips for sustainable education. This framework outlines a more integrated view of conceptual and procedural knowledge in the discipline of geography. The notion of geography competence may have an increasing influence on geography teaching, both in terms of methodology and the goals that learners are supposed to achieve. A geography competence-based syllabus needs to set out a variety of geographical abilities that the learner should be able to demonstrate at the end of a prescribed course or period of learning. Fieldtrips embody a limited and concentrated learning period and are concerned with hands-on training of actual geography practice in a real context. The geography fieldtrip enhances the learner's integral knowledge-building process to become a world citizen by first-hand experience of environmental issues, and encourages learner commitment to the Earth's sustainability. For instance, residential field study of a karstic landscape may involve comprehensive analysis and assessment of the environmental impact of human exploitation on water resources so as to envisage a sustainable water management plan that helps maintain optimal water-table levels. In order to evaluate a learner's performance of demonstrated geographical abilities during a fieldtrip, some geography competence-oriented assessment procedures and tools are specifically required. 


\subsection{The Notion of Geography Competence for Sustainable Education in the Geographical Education Syllabus}

Ever since the notion of competence, defined as a combination of knowledge, skills, and attitudes appropriate to the context, was introduced into the European Reference Curriculum Framework, there has been significant curricular development in relation to the adoption of the key competences. These are the competences that all individuals need for personal fulfilment and development, active citizenship, social inclusion, and employment [1]. However, scarce research has been conducted on the notion of competence in the discipline of geography, apart from the work by Partoune, Dewey, and MérenneSchoumaker [2].

The traditional syllabus lays a considerable emphasis on geography conceptual knowledge. Competence in geographical concepts is a necessary, though not sufficient, condition for achieving full disciplinary competence. The notion of geography competence needs to be expanded to embrace what the learner needs to know about how geography content is used in particular situations for effective and appropriate application to the geographical context. This is the ability to use and apply conceptual knowledge to the geographic space.

Thus, disciplinary competence in geography should encompass both conceptual and procedural knowledge. As a result, a modern syllabus may show a healthier and more proportional balance between the development of competence in geographical knowledge and of competence in its real application, in view of satisfactory learner performance. In this way, the proportion of content-oriented knowledge may be increasingly altered in favour of application-oriented skills as the learner progresses from novice to master level.

Geography competence can be described and articulated by a subset of competences, underpinned by thinking and reasoning processes and abilities. Geography competence development is measured by the degree of learner performance in the form of a set of geoabilities and geoskills. A major cognitive ability in geography competence is geospatial thinking that uses "geospace," Earth space, or geographic space at different scales to frame problems, identify answers, and provide solutions by employing geospatial concepts, representation tools, and reasoning processes [3]. Geographic thinking and reasoning focus on such spatial concepts as scale transformation, spatial association, distance and direction changes, and location identification [4,5].

In brief, geography competence may be defined as a combination of knowledge, skills, and attitudes applied to the geographic space in actual learning environments. Such a geographic competence set fosters life-long learning, with geographical knowledge applied in active citizenship decision-making in the geographic space. For instance, developing geospatial-thinking skills is related to mastering geospatial orientation in order to employ mobile GPS devices.

Furthermore, a holistic geography syllabus should engage in education for sustainable development to equip learners with knowledge, skills, understanding, attitude, and values compatible with sustainable development [6]. In this sense, the geography syllabus may encourage attitudes that contribute to sustainable development, making learners even more ethically and socially concerned with a sustainable geospace. In 1987, the Bruntland Report first approached the notion of sustainable development as relating to limitations imposed on environmental resources by the ability of the biosphere to absorb the effects of human activities [7].

As 'the science for sustainability', geography empowers learners to develop the knowledge and the skills and to employ the tools to adapt to and mitigate global environmental change [8]. According to Goudie, seven areas may be highlighted as foci for a more unified and valuable geography: (1) the study of hazards and disasters, and of resilience and vulnerability; (2) global changes and their causes, mitigation, and adaption; (3) Earth System Science; (4) human impacts; (5) the Anthropocene; (6) environmental history and environmental influences on human history and prehistory, including migration and settlement abandonment; and (7) the study and appreciation of landscape [9] (p. 20). These areas may be associated with sustainable development and are topics on sustainability to deal with in 
a geography fieldtrip. The geography fieldtrip thus contributes to sustainable education by fostering learner awareness, commitment, and values in relation to environmental preservation and land protection.

\subsection{The Fieldtrip as a Teaching Strategy}

In this proposal, while fieldwork is a key research technique in the academic context where empirical data are collected for analysis to conduct research, fieldtrips are a global and cross-disciplinary procedural teaching strategy that help prove students' level of comprehensive learning achieved in a discipline.

According to existing literature on geographic fieldwork, fieldwork is any subjectrelated arena in an outdoor setting for supervised learning via first-hand experience [10], and includes field teaching, field trip, field research, or field camp [11]. Fieldwork, whichever type of activity is involved [12], stands out as a defining feature of the discipline and a relevant learning mode with pedagogical benefits for students [13-22]. Both geography fieldwork and fieldtrips provide first-hand, direct experience of the real world, help promote active learning $[15,19,23-28]$, and offer relevant conceptual, cognitive, procedural, and social benefits to students [29]. Furthermore, well-integrated, course-aligned fieldwork and fieldtrips contribute to effective field teaching $[12,15,30,31]$ and to the notion of a spiral curriculum by deepening understanding of class-based geographical features and concepts [32].

The geography fieldtrip is a well-established learning mode in geography teaching. In geographical education, however, there is a lack of clearly predetermined assessable competences in the geography fieldtrip to enable educators to make judgements about a learner's geographical thinking, knowledge, and competences (i.e., abilities and skills) [20,33]. The geography fieldtrip as a procedural strategy encourages students to not only observe, identify, classify, and compare geographical facts, but also to conduct analysis, synthesis, and interpretation of these facts in a given place and time [34]. Moreover, the geography fieldtrip helps learners identify anthropic impacts on the landscape, evaluate the resulting changes and imbalances in nature, and raise awareness of the potential consequences for the natural environment.

The fieldtrip prepares students for applying and connecting knowledge in a real context $[15,27,35]$. The fieldtrip provides learners with a landscape reading that helps them point out the relevant features and set relationships among landforms for their understanding of landscape dynamics and evolution [36]. Precisely, the fieldtrip must offer an underlying and expressive record of the different landmarks on the route. In this sense, both elaborating sketches and drawings and conducting interviews with the inhabitants of the studied territories are ideal skills to develop during a geography fieldtrip. To this end, students should be able to collect and process data, and then to apply such data in a graphic way by means of figures, population pyramids, and cartography.

In the present proposal, while the fieldtrip is the teaching strategy, enquiry is adopted as the learning method, by which learners may gradually acquire further learning autonomy in a socio-constructivist learning environment. This learning method is the key to engaging in a closer dialogue with students and to holding their attention and interest [37-39]. The didactic approach here is project-based learning, where the project is built upon a realworld acute question of the students' interest and choice [40], and to which solutions are reached either by an enquiry learning method or through a problem-solving method. In problem-based learning, students are confronted with acute geoscenarios [34] where they must first identify and define the problem and then provide solutions on the basis of the natural and social needs and realities that have been clearly highlighted [41-43]. Their engagement in real-world issues enhances learning outcomes and helps students make a difference in practice [7].

The fieldtrip may well fit within a constructivist learning environment that is centred on the student's activity [41,44-46], where meaningful learning [47,48], discovery learning [49], and peer learning [50] foster students' autonomous and self-regulated learning and 
promote attention to diversity. Part of these types of learning are the didactic requirements for checking learner achievement through assessment.

Finally, the notion of experiential learning does not just involve "learning by doing" or having an authentic experience in an immersive and relevant setting. Fieldtrips are here conceived as an innovative kind of experiential learning from a holistic approach, where the full experiential learning cycle is completed during the fieldtrip experience itself [51]. The fieldtrip is embedded into an integral project completion whose design is determined by four factors (underlying thesis, project question, real-world settings, and sustainable solution). The fieldtrip discourse is based on the underlying thesis and articulated by the outstanding theme and landmark-related topics.

\section{Background to a Geography Competence-Oriented Fieldtrip Assessment Framework}

\subsection{Fieldtrip Assessment}

The present fieldtrip-applied assessment framework is concerned with student assessment, a term pointing to the actual assessment of students' learning achievement, as opposed to curriculum evaluation, a term relating to the evaluation carried out in all didactic interventions, that is, the implementation of any teaching approach, according to the distinction made by McCormick and James [52]. In the present analysis, fieldtrip assessment is aimed at reviewing the student's learning outcomes, and thus at identifying strengths and weaknesses of the student's learning. In this respect, the method is formative assessment, according to Kent, Gilbertson and Hunt's ideal sort of fieldtrip assessment and considering the fact that "the assessment method should always complement the teaching and learning strategy and be considered at the initial planning phase" [15] (p. 323). It is hard to find papers on assessing the learning achieved by students in a geography fieldtrip, yet Kinder, Kitchen, and Maddison present new guidelines on the fieldtrip [53,54].

A few decades ago, assessment was a challenge in the teaching of geography [55-60]. Some research has been conducted on a type of assessment of spatial ability [61]. More recently, clarity is advocated with regards to the essential geographical knowledge and skills, the nature of the learning progress in each of these areas, and the types and formats of assessment instruments that are required in geography assessment [62]. In this study, priority is given to the geographical knowledge and skill-set that students should demonstrate in a fieldtrip. To measure the level of the previously-acquired disciplinary conceptual and procedural competence, a variety of geographical abilities and skills are shown in a fieldtrip that need to be assessed, e.g., the ability to set relationships of similarity, difference, and hierarchy on landforms in a landscape.

Since the progression in student learning needs to be recorded [62], systematising the design and development of fieldtrip assessment is required in order to check the level of competence and the degree of ability demonstrated by students through fieldtrip evidence. Evidence of learning outcomes should be gathered from the previously selected and defined tasks that can be assessed by means of rubrics and grading criteria [63]. This evidencecentred design approach focuses on the interaction between geographic knowledge and assessable skills, for instance, by proving the student's geoability to reason about geospatial concepts that has been both acquired and developed. These fieldtrip evidence, along with other observations of each student, may be registered by the teacher on a "class $\log$ ". In order to obtain fieldtrip evidence, learners must be assigned geographical and cross-cutting tasks that must be clearly designed and defined to make a valid collection if they are to be accurately performed.

Decision-making on learning outcomes may be based on the curriculum framework of reference. Cognitive objectives may be selected from Bloom's Taxonomy [64-67], and psychomotor objectives [68,69] and other objectives from alternative taxonomies [70-75] may be included. The tasks may be oriented towards the cognition actions described in Bloom's taxonomy. Thus, comparing, describing, analysing, calculating, elaborating, explaining, predicting, and justifying are the set of actions that make it possible to confirm the learning outcomes $[44,45]$. 


\subsection{Fieldtrip-Applied Geography and Cross-Cutting Competences}

Main geographical and cross-cutting competences, abilities, and skills are identified [76-81] and included in this analysis for competence assessment in a fieldtrip [82]. Key competences in geography learning have been incorporated and compared to $[2,83]$. Generally speaking, geographical competences have been associated with an array of abilities and corresponding skills: logical-cognitive skills (concepts and procedures), abstract spatial and geospatial skills (orientation, direction, location), instrumental skills, computational skills, and analogical skills.

First, logical-cognitive abilities are developed to apprehend, understand, define, compare, and analyse concepts $[39,84-86]$ by stimulating learner thinking and reasoning processes. Geographical key concepts are used to organise and link content in geography lessons. That is a means of creating progress concerning the students' cumulative learning and their geographical thinking skills. Key concepts could be defined as subject-specific ideas that emerge from the structure of a subject describing the most relevant processes and phenomena. The understanding of a conceptual framework helps students see geography as an intellectual core of knowledge rather than as a set of disparate units of study [87].

Second, research studies on geospatial thinking and skills are approached from different perspectives [88-90]. Abstract spatial and geospatial skills [82,91] are applied by employing abstract, spatial, and geospatial thinking $[61,92,93]$ to comprehend orientation and way-finding and to follow directions to a location in urban and natural environments by means of representation tools, including printed material (plans and maps) as well as virtual and analogical devices (smartphones and GPS tools). Geospatial skills are also developed by employing analogical reasoning to compare cartographical representation with geospace.

Third, instrumental skills involve abstract and real applications of analogic and/or digital/virtual resources to the geospace for cartography reading [92,94,95], for instance, the use of a compass to take a bearing on a specific location or of on/offline cartography to identify, select, and interpret geographical settings, as well as the application of geographical notions to land management. ITC and GIS curation in documentation and cartography involve fieldtrip tasks such as geographical landmark location and route planning. Both tasks require learners to master the search and retrieval of documentation on websites, as well as the use of cartographic viewers for route planning on an online map.

Fourth, computational skills are used to search for and select maps, to plan routes, and spot landmarks on a fieldtrip track. "Computational thinking is reformulating a seemingly difficult problem into one we know how to solve, perhaps by reduction, embedding, transformation, or simulation" [96] (p. 33). Computational thinking involves recursive thinking and promotes the ability to identify and analyse geospatial correlation among geospatial parameters for inferring recursive models.

Fifth, the analogical skill in geography prepares for abstraction, since relationships of similarity and difference are set between two geographical phenomena [97]. The analogical transfer facilitates everyday spatial problem-solving and contributes to elaborating on abstract and real-life ideas and models of abstract and real-life phenomena [98,99]; it may therefore be a suitable kind of reasoning process to apply to fieldtrips. Analogical thinking also encourages creativity [100].

Regarding cross-cutting competences, much of the development of thinking on capabilities in education comes from Nussbaum [101]. Democratic citizenship, Nussbaum points out, turns out to be key in society and seems to be threatened by an education centred on the instruction of instrumental areas. In a society characterized by the economic drive, skills linked to the humanities and the arts must be fostered to shape citizenship. The cross-cutting feature of competence, nowadays, is interdisciplinarity, as recognised by Roegiers [102]. Cross-cutting skills are narrative, mathematical, personal, social, and creative skills.

Narrative skills of oral and written expression are crucial to analysing, synthesising, and interpreting information [103]. Deep learning can be promoted in fieldtrips by en- 
couraging reflective practices, such as keeping a reflective fieldtrip diary, which enhances written communication skills and, in particular, encourages development in communicating self-reflection [104]. Learner assignments are the examples behind the instructional narrative that teachers may identify as a type of narrative skill and, consequently, value as educational and training possibilities $[105,106]$. There is a trend between geography and communication concerning a set of issues (representations, textures, structures, and connections) [107]. Communication ability allows for the building up of the fieldtrip discourse. This ability fosters the learner's narrative skill of reconstructing the underlying thesis of the fieldtrip project and elaborating on the fieldtrip discourse. That is how, from the selection of geographical landmarks of the learner's choice, the students may deliver a discourse based on the fieldtrip's underlying thesis by means of a composition on outstanding theme and landmark-related topics.

Mathematical skills afford the design of figures and tables that are expressive of collected data, analysis, and discussion on results. The ability to obtain and apply data in offline mapping is essential to cartographical information and to estimating calculations during fieldtrips. Euclidean geometry is employed in the survey of small areas in the field, while spherical geometry and trigonometry are needed in the construction of map projections. Statistical techniques can be applied to the description and analysis of geographical data [108].

Personal and social skills involve intra/interpersonal collaboration and social commitment, and help raise awareness about the natural and cultural environment [109]. In relation to both personal development and social skills, the fieldtrip proves its worth by promoting such social skills as empathy and solidarity [18].

Creative skills are related to personal relationships, communication, and formation of critical thinking. Critical thinking promotes debate on geography issues in geographical education, such as climate change, sustainability, and social exclusion. Critical thinking skills are developed when participating in debates through presentations, arguments, and roles [110]. Critical thinking, a capacity defined as spatial citizenship, fosters knowledge and reflective interpretation of spatial problems during the fieldtrip and helps to build a committed and engaged society [111,112].

The integral application of both geography competences and cross-cutting competences in the geography fieldtrip may encourage sustainable education. Geographical thinking may lead to learners having a better understanding of the world around them that transcends subject boundaries and helps them tackle what in political theory are known as essentially contested concepts (such as the concept of justice) [113]. Understanding the conceptual implications of geographical terms such as "slum" and "suburb" enables learners to analyse environmental injustices and interpret land and social inequities. In this sense, sustainability challenges us to think in a holistic way, and about the contested nature of the concept $[19,114]$.

Some decades ago, key competences of geography were identified [2] that are fully applicable to the fieldtrip. These geography competences do, in fact, correspond to geoabilities, which may be associated with the geography and cross-cutting competences in the present assessment framework (Table 1). Thus, the competence being identified by these authors as "travelling through an unfamiliar space without getting lost" is in fact a geospatial competence. When applying the geoability of "reading a new landscape", it is the analogical competence that is mainly developed, a competence by which meaningful geographic knowledge of other geographic spaces is found to correlate with the ability of landscape reading. However, the essence of analogical competence lies in setting relationships of similarity and difference among known landscapes, and between known and unknown landscapes. 
Table 1. Comparison of geography competences [2] with the geography and cross-cutting competences in the present assessment framework proposal (author's design).

\begin{tabular}{cc}
\hline Geography Competences [2] & $\begin{array}{c}\text { Geography and Cross-Cutting } \\
\text { Competences }\end{array}$ \\
\hline Travelling through an unfamiliar space without getting lost & Geospatial Competence \\
\hline Locating events in a table of specialised references & Geo-logical Competence \\
\hline Showing a personalised spatial image of their "spaces" & Intra/Interpersonal Competence \\
\hline Reading a new landscape & Analogical Competence \\
\hline Designing maps, diagrams and sketches & Computational Competence \\
\hline Scaffolding spatial models at different scales & Creative Competence \\
\hline Planning a track of discovery in a place of the \\
natural environment & Narrative Competence \\
\hline $\begin{array}{c}\text { Assessing the effects of consumption of certain } \\
\text { everyday products }\end{array}$ & Critical Competence \\
\hline
\end{tabular}

In brief, there is a particular set of geography competences and cross-cutting competences that must be developed in geography fieldtrips. The geography competence embodies a subset of competences: geo-logical competence, geospatial competence, computational competence, and analogical competence. These geographical competences are developed by a corresponding set of geoabilities and geoskills. Cross-cutting competences are mathematical competence, narrative competence, intra/interpersonal competence, critical competence, and creative competence.

For sustainable education, besides geography competences, especially the geospatial competence, certain cross-cutting competences are needed to attain an integral and engaged citizenship education in landscape sustainability and geospace sustainable development. Of the cross-cutting competence set, the creative, critical and intra/interpersonal competences may be most relevant to sustainable education. Analysing the sustainable use of water resources on a karstic landscape requires both geographical knowledge on landform processes and features and geoabilities to detect major watercourses and that direction of water flow. Furthermore, abilities of critical thinking are also needed for assessing the sustainability of anthropic interventions on the landscape for water exploitation. By applying the creative competence, learners may be able to figure out appropriate and feasible solutions to an acute social issue (e.g., sustainable water management). Through the development of the intra/interpersonal competence, which is intertwined with social abilities, students are able to discuss and share ideas and to be respectful of other opinions in order to reach consensus on the most sustainable solution for the environment.

\subsection{Fieldtrip Geoskills}

By adopting the project-based learning approach, the fieldtrip project is structured upon a real-world acute question of the students' interest. Students must put forward solutions following the enquiry learning method [39]. This action involves developing certain enquiry skills throughout the project to reach an optimal solution to the project question. This enquiry learning method is applicable to all domains of geography teaching where the geo-logical, mathematical, and narrative competences are dominant, since the enquiry skill proposal [39] does not in fact cover all the competences that are required in a fieldtrip. This reveals that a more significant and stronger presence of the geospatial and critical competences is missing (Table 2). As a result, fieldtrips demand further teaching guidance for holistic competence development. 
Table 2. Correlation of enquiry skills [39] to major and complementary fieldtrip geography and cross-cutting competences in the present assessment framework proposal (author's design).

\begin{tabular}{|c|c|c|}
\hline Enquiry Skills [39] & $\begin{array}{l}\text { Major Fieldtrip } \\
\text { Competences }\end{array}$ & $\begin{array}{c}\text { Complementary Fieldtrip } \\
\text { Competences }\end{array}$ \\
\hline $\begin{array}{l}\text { Formulate appropriate } \\
\text { geographical questions }\end{array}$ & Geo-Logical Competence & Narrative Competence \\
\hline $\begin{array}{l}\text { Develop techniques for collecting } \\
\text { primary data in the field }\end{array}$ & Geospatial Competence & Mathematical Competence \\
\hline $\begin{array}{l}\text { Research secondary evidence from a } \\
\text { wide range of sources }\end{array}$ & Geo-Logical Competence & Mathematical Competence \\
\hline $\begin{array}{l}\text { Analyse quantitative and digital data } \\
\text { using numerical and statistical skills }\end{array}$ & Mathematical Competence & $\begin{array}{l}\text { Computational } \\
\text { Competence }\end{array}$ \\
\hline $\begin{array}{c}\text { Interpret qualitative data from a } \\
\text { range of sources: interviews, textual, } \\
\text { and visual }\end{array}$ & Geo-Logical Competence & Mathematical Competence \\
\hline $\begin{array}{l}\text { Evaluate the accuracy, reliability, and } \\
\text { validity of data used as evidence }\end{array}$ & Mathematical Competence & Geo-Logical Competence \\
\hline Recognise bias and assumptions & Critical Competence & Narrative Competence \\
\hline $\begin{array}{l}\text { Relate data and findings to existing } \\
\text { theoretical understandings }\end{array}$ & Geo-Logical Competence & Narrative Competence \\
\hline Identify patterns and relationships & Analogical Competence & Critical Competence \\
\hline $\begin{array}{c}\text { Form reasoned arguments and } \\
\text { qualify them }\end{array}$ & Narrative Competence & Creative Competence \\
\hline $\begin{array}{l}\text { Justify conclusions using evidence } \\
\text { and reasoned arguments informed by } \\
\text { wider theory }\end{array}$ & Narrative Competence & Creative Competence \\
\hline $\begin{array}{l}\text { Present findings using cartographic, } \\
\text { graphical, communication, and } \\
\text { literacy skills }\end{array}$ & Geospatial Competence & Mathematical Competence \\
\hline $\begin{array}{l}\text { Reflect on the investigation; assess the } \\
\text { extent to which questions have } \\
\text { been addressed }\end{array}$ & Critical Competence & Creative Competence \\
\hline $\begin{array}{l}\text { Evaluate the strengths and } \\
\text { weaknesses of the methodology, data, } \\
\text { and conclusions }\end{array}$ & Narrative Competence & Critical Competence \\
\hline
\end{tabular}

\section{Geography Competence-Oriented Fieldtrip Assessment Proposal}

This proposal is built upon the aforementioned lack of previous literature and/or guidelines' on how to evaluate learner performance in a geography fieldtrip. The question leading to the present analysis of how to assess the level of predetermined geographical competences and the degree of corresponding geoability/geoskill achieved by students during a fieldtrip is posed after having conducted many fieldtrips in geographical education. The instructional need for a geography competence-oriented fieldtrip assessment framework arises from educational practice.

\subsection{Fieldtrip Assessment Framework}

The present intention is to identify and frame the assessable geographical and crosscutting competences that may be developed during the fieldtrip. The present proposal is based on a selection of the cognitive domain (geographical thinking) and cognitive process (geospatial thinking), geographical and cross-cutting competences, corresponding geoabilities and geoskills, and learning outcomes in the geography fieldtrip. In the present geographical thinking approach to the fieldtrip, the geographical competences and the 
cross-cutting competences are interrelated. Geospatial thinking has been selected due to its being both the guiding and prevailing cognitive process in steering the fieldtrip, and the dominant cognitive process underpinning the competences (Table 3).

Table 3. Geography competence-oriented fieldtrip assessment framework with alignment of geographical thinking linked to geospatial thinking, geography and cross-cutting competences, geoabilities, geoskills, and learning outcomes (author's design).

\begin{tabular}{|c|c|c|c|c|c|}
\hline & \multicolumn{5}{|c|}{ Geospatial Thinking } \\
\hline \multirow{8}{*}{$\begin{array}{l}\text { Geographical } \\
\text { Thinking }\end{array}$} & \multirow{4}{*}{$\begin{array}{l}\text { Geography } \\
\text { Competences }\end{array}$} & $\begin{array}{c}\text { Geospatial } \\
\text { Competence }\end{array}$ & Land Planning & $\begin{array}{l}\text { Planning conditions for } \\
\text { a sustainable landscape }\end{array}$ & Identify landscape needs \\
\hline & & $\begin{array}{l}\text { Analogical } \\
\text { Competence }\end{array}$ & $\begin{array}{l}\text { Cultural } \\
\text { Landscape } \\
\text { comparing }\end{array}$ & $\begin{array}{l}\text { Reading a new } \\
\text { Landscape }\end{array}$ & $\begin{array}{l}\text { Recognise relevant } \\
\text { landscape features }\end{array}$ \\
\hline & & $\begin{array}{l}\text { Computational } \\
\text { Competence }\end{array}$ & GIS Geoability & Route planning & $\begin{array}{c}\text { Design a simple } \\
\text { cartogram by employing } \\
\text { online tools }\end{array}$ \\
\hline & & $\begin{array}{l}\text { Geo-Logical } \\
\text { Competence }\end{array}$ & $\begin{array}{l}\text { Cartography } \\
\text { Literacy }\end{array}$ & Locating landmarks & $\begin{array}{l}\text { Plan a route by } \\
\text { correlating waypoints }\end{array}$ \\
\hline & \multirow{5}{*}{$\begin{array}{l}\text { Cross-cutting } \\
\text { Competences }\end{array}$} & $\begin{array}{l}\text { Mathematical } \\
\text { Competence }\end{array}$ & $\begin{array}{l}\text { ICT Curator } \\
\text { Ability }\end{array}$ & $\begin{array}{c}\text { Comparing } \\
\text { geographical projections }\end{array}$ & $\begin{array}{l}\text { Propose graphical } \\
\text { restitution from aerial } \\
\text { photographs and } \\
\text { historical maps }\end{array}$ \\
\hline & & $\begin{array}{c}\text { Narrative } \\
\text { Competence }\end{array}$ & $\begin{array}{l}\text { Communicative } \\
\text { Ability }\end{array}$ & Describing landmarks & $\begin{array}{l}\text { Build the fieldtrip } \\
\text { discourse }\end{array}$ \\
\hline & & $\begin{array}{c}\text { Critical } \\
\text { Competence }\end{array}$ & $\begin{array}{c}\text { Engaged } \\
\text { Citizenship }\end{array}$ & $\begin{array}{l}\text { Assessing the impact of } \\
\text { unsustainable use on } \\
\text { natural resources }\end{array}$ & $\begin{array}{l}\text { Reason out a sustainable } \\
\text { solution to natural } \\
\text { resource exploitation }\end{array}$ \\
\hline & & $\begin{array}{l}\text { Creative } \\
\text { Competence }\end{array}$ & Social Ability & $\begin{array}{l}\text { Reaching consensus in } \\
\text { problem solving and } \\
\text { decision making on } \\
\text { acute emerging } \\
\text { geographical issues }\end{array}$ & $\begin{array}{l}\text { Discover collaborative } \\
\text { solutions to acute } \\
\text { emerging natural and } \\
\text { social needs and realities }\end{array}$ \\
\hline & & Competences & Geoabilities & Geoskills & Learning outcomes \\
\hline
\end{tabular}

In the light of such a geography competence-oriented fieldtrip assessment framework, geographical thinking, geospatial thinking, geography and cross-cutting competences, and geoabilities and geoskills are aligned, as well as assessment levels and learning patterns. This assessment proposal shows the significant educational dimensions involved in the assessment of a geography fieldtrip, its processes, and achievements: the thinking and reasoning domain, geography and cross-cutting competences, and geoabilities and geoskills, among which there is a hierarchical correlation.

This framework represents a hierarchical and flux construct, ranging from the most abstract thinking processes to more practical and specific learning outcomes. For instance, the geoskill of "describing landmarks" pertaining to the cross-cutting narrative competence is used to identify, describe, and correlate predetermined landmarks and their features on the fieldtrip route, while interpreting and debating on landscape value. The communicative ability allows for reconstructing the underlying fieldtrip thesis from the identified landmarks on the route by linking past and present geographical elements and facts around an outstanding and dominant landscape feature (the theme). Then, the communicative ability is developed to produce a narrative or structured discourse based on such outstanding theme and landmark-related topics, whose learning outcome is to build the fieldtrip discourse. 


\subsection{Assessment Procedure}

In this geography competence-oriented fieldtrip assessment framework, the chosen didactic approach determines the selection of geographical knowledge, competence, and skill-set that students should demonstrate in a fieldtrip. In project-based learning approach, the fieldtrip is built upon a real-world acute question of learner interest that is solved by students following the enquiry learning method. Depending on the question and project type, learners may apply and show the set of geoskills pertinent to the actions and steps that enable them to reach an optimal solution.

In the fieldtrip, competence development is measured by the degree of learner performance in the form of a set of geoskills. The level of the geoskills being displayed throughout the project needs to be assessed. Assessing fieldtrip geoskills involves the formulation of learning standards (goals), tasks, learning outcomes, and assessment evidence.

In the present proposal, some tasks and assessment evidence are provided for each geoskill. For instance, for the geoskill of "interpreting different types of panoramic, aerial, and satellite photographs", the task is to analyse sustainable/unsustainable changes in landscape, and the assessment evidence is a landscape interpretation survey based on photographs and maps. During the fieldtrip, the students use navigation tools and panoramic, aerial, and satellite photographs. These analogical and digital resources allow them to identify landmarks that may represent geographical elements and/or facts in the landscape. The elements are natural features (e.g., hills, mountains, rivers, springs) or social and cultural features (e.g., churches, villages, artefacts), and the geographical facts are the interactions among natural and cultural elements (e.g., agricultural or farming lands, enclosures, population settlements, irrigation ditches, etc.) that make it possible to reconstruct the underlying thesis of the fieldtrip project and elaborate on the fieldtrip discourse. For instance, water may be the determining factor around which elements and facts are grouped and correlated: the natural elements associated with water (e.g., spring, water table, watershed, waterway, river terrace) and the facts of water exploitation (e.g., wells, watermills, irrigation ditches, fisheries, aquaculture, etc.).

In order to identify and recognise real-world settings, a threefold step should be taken to develop this geoskill: (1) identify the element(s) (e.g., river bank or terrace) and/or the fact(s) (e.g., a watermill) in the given photographs; (2) geolocate the elements and facts in the photograph and in the real setting; and (3) correlate the location and state of the elements and/or facts in the photographical and cartographical representations to the real setting. The task consists of analysing the unsustainable use of natural resources (e.g., water resources) that may exceed the carrying capacity of the natural system (e.g., variations in water table levels) and thus compromise its regenerative capacities (e.g., springs running dry, decrease of water flow provoking watermill blockage, and drying of wells). The assessment evidence is a landscape survey of environmental changes as a response to variations in water table levels that may be fatal for ecosystem survival and sustainability (Table 4).

\subsection{Fieldtrip Geoskill Assessment Tools}

The assessment evidence resulting from the tasks performed during the fieldtrip project may be assessed by assessment tools, namely rubrics. An assessment rubric with corresponding grading criteria is hereto provided as a tool for assessing a particular task consisting of planning a route on both an online and an offline map.

The assessment evidence of learning outcomes may be marked and graded through rubrics that enable teachers to detect the degree of task accomplishment and the level of learning outcome achievement. A rubric must contain qualitative and quantitative grading to express the final assessment score of the demonstrated fieldtrip competence. All assessment evidence may be measured by an assessment rubric. This assessment rubric may include at least five vertical entries to record all learning outcomes that are required to produce the evidence. In the present proposal of a quantitative rubric, each grading is scored over 20 points up to a total of 100 points, as there are five achievement ranges. 
Table 4. Geoskills linked to tasks and assessment evidence. Author's design.

\begin{tabular}{|c|c|c|}
\hline Geoskills & Tasks & Assessment Evidence \\
\hline $\begin{array}{l}\text { Identifying the determining factors } \\
\text { for a sustainable landscape }\end{array}$ & Formulate fieldtrip acute question & $\begin{array}{l}\text { A photograph or drawing illustrating the } \\
\text { acute issue }\end{array}$ \\
\hline $\begin{array}{l}\text { Choosing the outstanding landmarks } \\
\text { for route planning }\end{array}$ & $\begin{array}{c}\text { Plan the fieldtrip route on both online and } \\
\text { offline maps by identifying and marking } \\
\text { map landmarks }\end{array}$ & Route plan on both online and offline maps \\
\hline \multirow{4}{*}{$\begin{array}{l}\text { Collecting field samples, evidence, } \\
\text { and records to interpret the } \\
\text { cultural landscape }\end{array}$} & $\begin{array}{l}\text { Gather field samples and fulfil an } \\
\text { identification form }\end{array}$ & $\begin{array}{l}\text { Sample identification form duly fulfilled } \\
\text { for classification }\end{array}$ \\
\hline & $\begin{array}{l}\text { Design a checklist to verify fieldtrip data } \\
\text { accuracy and validity }\end{array}$ & Data validation checklist \\
\hline & $\begin{array}{c}\text { Draw landscape components and features } \\
\text { on the fieldtrip notebook }\end{array}$ & Landscape sketches \\
\hline & $\begin{array}{l}\text { Prepare a semi-structured interview for } \\
\text { population and economic activity } \\
\text { survey purposes }\end{array}$ & Semi-structured interview \\
\hline $\begin{array}{l}\text { Curating historical, cartographical, } \\
\text { and literary documentation }\end{array}$ & $\begin{array}{l}\text { Choose and discriminate reliable and } \\
\text { accurate documentary sources }\end{array}$ & $\begin{array}{l}\text { Record of retrieved historical, } \\
\text { cartographical, and literary documentation }\end{array}$ \\
\hline $\begin{array}{l}\text { Creating a fieldtrip database of } \\
\text { statistical data }\end{array}$ & $\begin{array}{l}\text { From a table with statistical data, build a } \\
\text { representation tool for statistical } \\
\text { data processing }\end{array}$ & $\begin{array}{l}\text { Representation tool with statistical data } \\
\text { figures (statistical data chart, population } \\
\text { pyramid, climate graph) }\end{array}$ \\
\hline $\begin{array}{l}\text { Reading and analysis of landscape } \\
\text { maps and photographs }\end{array}$ & $\begin{array}{l}\text { Outline geographical features on a } \\
\text { topographical map }\end{array}$ & Landscape cartographical scheme \\
\hline $\begin{array}{l}\text { Interpreting different types of } \\
\text { panoramic, aerial, and } \\
\text { satellite photographs }\end{array}$ & $\begin{array}{l}\text { Analyse sustainable/unsustainable } \\
\text { changes in landscape }\end{array}$ & $\begin{array}{l}\text { Landscape interpretation survey based on } \\
\text { photographs and maps }\end{array}$ \\
\hline $\begin{array}{l}\text { Describing and correlating landmarks } \\
\text { to build a fieldtrip discourse }\end{array}$ & $\begin{array}{l}\text { Debate and write in small groups on the } \\
\text { outstanding theme and } \\
\text { landmark-related topics }\end{array}$ & $\begin{array}{l}\text { Small-group composition on debated } \\
\text { fieldtrip theme and topics }\end{array}$ \\
\hline $\begin{array}{l}\text { Linking field data and evidence to } \\
\text { geographical theories }\end{array}$ & $\begin{array}{l}\text { Debate on the relationship between field } \\
\text { data and evidence and theories of earth } \\
\text { and climate dynamics }\end{array}$ & $\begin{array}{l}\text { Reflective essay on association of field data } \\
\text { and evidence to theories of earth and } \\
\text { climate dynamics }\end{array}$ \\
\hline $\begin{array}{l}\text { Setting analogical relationships } \\
\text { (similarity and difference) }\end{array}$ & Identify and relate landscape landforms & $\begin{array}{l}\text { Table illustrating relationships among } \\
\text { landscape landforms }\end{array}$ \\
\hline \multirow{2}{*}{$\begin{array}{l}\text { Building and developing an } \\
\text { argument from different social actor } \\
\text { and citizenship positions on an acute } \\
\text { landscape issue }\end{array}$} & $\begin{array}{c}\text { Carry out interviews with key landscape } \\
\text { actors in small survey teams to produce a } \\
\text { video showing different positions on an } \\
\text { acute issue }\end{array}$ & $\begin{array}{c}\text { Video presentation of interviews with key } \\
\text { landscape actors }\end{array}$ \\
\hline & $\begin{array}{l}\text { Participate in a debate through role play by } \\
\text { presenting a sound argument on an } \\
\text { acute issue }\end{array}$ & $\begin{array}{l}\text { Presentation with reasoned argument and } \\
\text { conclusions on landscape expectations }\end{array}$ \\
\hline $\begin{array}{l}\text { Detecting unsustainable practices } \\
\text { in a landscape }\end{array}$ & $\begin{array}{l}\text { Write down a file on unsustainable } \\
\text { landscape practices }\end{array}$ & File on unsustainable landscape practices \\
\hline Mapping fieldtrip findings & $\begin{array}{l}\text { Classify and map fieldtrip findings and } \\
\text { field samples }\end{array}$ & $\begin{array}{l}\text { Cartogram with fieldtrip route and } \\
\text { landmarks, and record of field samples }\end{array}$ \\
\hline $\begin{array}{l}\text { Identifying anthropic impacts } \\
\text { on the landscape }\end{array}$ & \multirow{2}{*}{$\begin{array}{l}\text { Drafting conclusions on the project } \\
\text { question with pros and cons weighing up } \\
\text { acute issues }\end{array}$} & \multirow[b]{2}{*}{$\begin{array}{l}\text { Final report with thesis on landscape } \\
\text { environmental and sustainability state }\end{array}$} \\
\hline $\begin{array}{l}\text { Evaluating landscape change and } \\
\text { consequences of unsustainable land } \\
\text { use, resource exploitation, } \\
\text { and consumption }\end{array}$ & & \\
\hline
\end{tabular}

The selected score is based on the five-point Likert scale, an ordinal bipolar scaling method that is most widely used to scale responses to items in survey research by measuring either a positive or negative response to a statement. In this rubric, the five-point Likert scale is adapted and applied for two main reasons: scope level and degree of discrimination [115]. First, this scaling enables the teacher to acknowledge the scope of the learner's acquired or 
developing knowledge, skills, and attitudes. Second, a five-level scaling makes it possible to identify and discriminate between different levels of learning achievement.

The proposal here for the assessment rubric of learning outcome evidence is the "route plan on both online and offline maps". This rubric helps the teacher record the various learning steps that have been taken in the development of a particular task in the fieldtrip project, namely, "plan the fieldtrip route on both online and offline maps by identifying and marking map landmarks". These records are listed in order of task accomplishment and consist of five entries of learning outcomes: (1) identify and mark five landmarks on the map; (2) gather and provide information of geographical, natural, and cultural issues on each of the five landmarks; (3) plan a route of choice between selected landmarks; (4) build a structured fieldtrip discourse from planned landmarks; and (5) employ GIS tools.

First, the number of landmarks is easily assessable; the grading is established in the rubric ranging from one to five correctly-identified landmarks. Second, a record file may be drafted with various data of interest, such as geographical data or natural and cultural issues of the visited places. Third, the route planning is associated with finding easily accessible pathways or places or shorter routes. The correct choice of the straightest segments between landmarks without detours and by accessible pathways will be best scored. Fourth, the fieldtrip discourse must address the acute question leading to the learning project accomplishment. Water exploitation may be an argument in problem-solving related to sustainable use as opposed to aquifer contamination. Finally, the application of GIS cartographic tools to route planning can be easily quantified (Table 5).

Table 5. Assessment rubric of learning outcome evidence: "Route plan on both online and offline maps" (author's design).

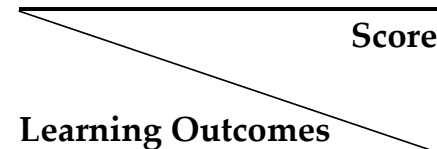

0-20

$21-40$

$41-60$

$61-80$

81-100

Learning Outcomes

Identify and mark five landmarks on the map
Spots unimportant Spots at least one landmarks
Among two or Spots almost all

three relevant the relevant Spots all the five landmarks, spots landmarks that relevant a non-relevant are pertinent to landmarks. the fieldtrip.

\section{Provides}

detailed and accurate

information in the

Gather and provide information of

Information missed in the record of geographical, natural, and some landmarks, or cultural issues on each of provides biased

the five landmarks information

\section{Provides}

detailed and information in the record of all the five landmarks accurate

\section{record of two}

landmarks, and

significant items of information are missing on some issues.

\section{information in} the record of at

least three

landmarks, but significant items of information are missing on

the rest.

\section{Provides} detailed and accurate information in the record of almost all landmarks, but a little information is missing on some issues.

\begin{tabular}{|c|c|c|c|c|c|}
\hline & & & rest. & 年 & \\
\hline $\begin{array}{c}\text { Plan a route of choice } \\
\text { between selected } \\
\text { landmarks }\end{array}$ & $\begin{array}{l}\text { Traces four route } \\
\text { segments } \\
\text { inaccurately or } \\
\text { traces accurately one } \\
\text { segment between } \\
\text { two landmarks }\end{array}$ & $\begin{array}{c}\text { Traces accurately } \\
\text { two route } \\
\text { segments }\end{array}$ & $\begin{array}{l}\text { Traces } \\
\text { accurately three } \\
\text { route segments }\end{array}$ & $\begin{array}{l}\text { Traces } \\
\text { accurately four } \\
\text { route segments }\end{array}$ & $\begin{array}{c}\text { Traces } \\
\text { accurately all } \\
\text { the five route } \\
\text { segments }\end{array}$ \\
\hline
\end{tabular}


Table 5. Cont.

\begin{tabular}{|c|c|c|c|c|c|}
\hline Learning Outcomes & $0-20$ & $21-40$ & $41-60$ & $61-80$ & $81-100$ \\
\hline $\begin{array}{c}\text { Build a structured fieldtrip } \\
\text { discourse from planned } \\
\text { landmarks by identifying } \\
\text { theme and topics }\end{array}$ & $\begin{array}{l}\text { Provides no } \\
\text { structured discourse }\end{array}$ & $\begin{array}{c}\text { Provides a poorly- } \\
\text { structured } \\
\text { discourse from at } \\
\text { least two } \\
\text { landmarks with } \\
\text { two subtopics to } \\
\text { build the fieldtrip } \\
\text { theme }\end{array}$ & $\begin{array}{c}\text { Provides a semi- } \\
\text { structured } \\
\text { - discourse from } \\
\text { three landmarks } \\
\text { with either a } \\
\text { clear theme, but } \\
\text { no subtopics, or } \\
\text { with several } \\
\text { subtopics, but no } \\
\text { explicit } \\
\text { identification of } \\
\text { the theme }\end{array}$ & $\begin{array}{l}\text { Provides a well- } \\
\text { structured } \\
\text { discourse from } \\
\text { four landmarks, } \\
\text { with expression } \\
\text { of the main } \\
\text { theme and some } \\
\text { of the subtopics }\end{array}$ & $\begin{array}{l}\text { Provides a } \\
\text { properly- } \\
\text { structured } \\
\text { discourse from } \\
\text { the five } \\
\text { landmarks, with } \\
\text { expression of } \\
\text { the main theme } \\
\text { and all the } \\
\text { related } \\
\text { subtopics }\end{array}$ \\
\hline Employ GIS tools & Employs no GIS tool & $\begin{array}{l}\text { Employs a GIS } \\
\text { tool, properly } \\
\text { locating a few } \\
\text { landmarks }\end{array}$ & $\begin{array}{l}\text { Employs a GIS } \\
\text { tool, properly } \\
\text { locating all } \\
\text { landmarks, but } \\
\text { correlating no } \\
\text { waypoints }\end{array}$ & $\begin{array}{l}\text { Employs a GIS } \\
\text { tool, properly } \\
\text { locating all } \\
\text { landmarks, but } \\
\text { erroneously } \\
\text { correlating at } \\
\text { least two } \\
\text { waypoints }\end{array}$ & $\begin{array}{l}\text { Employs a GIS } \\
\text { tool, properly } \\
\text { locating all } \\
\text { landmarks and } \\
\text { correctly } \\
\text { correlating all } \\
\text { waypoints }\end{array}$ \\
\hline
\end{tabular}

\section{Discussion}

The present fieldtrip assessment proposal was conceived to respond to the question of how to assess the level of predetermined geographical competences and the degree of corresponding geoability/geoskill achieved by students during a fieldtrip. In response to this challenge, a macro-analysis was conducted that explores the hierarchical relationship among the cognitive domain (geographical thinking) and process (geospatial thinking), geography and cross-cutting competences, corresponding geoabilities and geoskills, and learning outcomes in the geography fieldtrip. This analysis shows that developing geographical thinking in a fieldtrip requires not only a set of geography competences, but also cross-cutting competences for complementary purposes. This is in line with the updated European reference framework for key competences for lifelong learning, which underlines the innovative idea of the cross-cutting nature of key competences [116]. Key competences, namely the mathematical and narrative ones, have been proven to be essential in the development of certain geoskills in a fieldtrip (e.g., comparing geographical projections and describing landmarks).

In the present proposal, the enquiry approach has been chosen as the learning method [39] in project-based learning because it raises learner motivation, attention, and interest, and encourages deeper learning, as the project addresses a real-world acute question of learner interest and choice [40]. The fieldtrip promotes enquiry learning by actively engaging students in the learning process and encouraging further autonomy, social interaction, and group work. Fieldwork has proven to be a most useful and effective alternative strategy for learning science in which students are able to carry out an enquiry work from start to finish, both individually and by combining efforts through teamwork [29]. The enduring benefits of carefully thought-out fieldwork [29] may be greatly accrued in the context of the present fieldtrip proposal, since the fieldtrip is envisaged to be fully embedded into an integral project of students' interest and choice, in order for them to collaboratively 
reach an informed solution. To do so, learners must propose, reflect, share, and debate upon their own ideas arising from their observations in the field.

Following the enquiry skill proposal [39], the comparison of these enquiry skills to the fieldtrip competences has shown a bias in the application of enquiry skills in geography education. The analysis of such correlation underlines a notable reiteration frequency of geo-logical and narrative competences as major competences, and mathematical and creative competences as complementary ones. This means that the enquiry learning method privileges one competence of the geography-competence set (the geo-logical competence), and two competences of cross-cutting nature (narrative and mathematical competences). Therefore, should the enquiry-skill approach be employed as a learning method in a fieldtrip, a more proportional balance between the geography competences and the crosscutting competences would be most convenient. For developing a wider geoskill-set, the employ must be reinforced by online and offline maps and cartographic viewers, as well with tools for orientation, direction, and location of geographical elements and facts. Equally, critical thinking skills may be developed by analysing and interpreting the identified facts. In brief, in the present fieldtrip-applied framework, competence development also embraces geoskills from geospatial and critical competences.

The present geography competence-oriented fieldtrip assessment framework shows three strengths: applicability, adaptability, and replicability. First, this assessment framework may be applicable to geography fieldtrips in general that would adopt the projectbased learning approach or an enquiry learning method in a real non-virtual environment. When designing the fieldtrip project in a real environment, four determining factors should be met: underlying thesis (outstanding theme and landmark-related topics), project question, real-world settings, and sustainable solution. The fieldtrip project where the aforementioned field study of a karstic landscape is undertaken may be extrapolated to a real environment of a Mediterranean mountain landscape, with a forest rich in Scots pines (Pinus sylvestris) and holm oaks (Quercus ilex), and the presence of sawmills for timber extraction. In this landscape can they be easily identified the outstanding theme and landmark-related topics (e.g., forestry resources, timber extraction), project questions or issues (e.g., deforestation and abusive clearing), real-world settings (e.g., forest, sawmill sites), and sustainable solutions (e.g., sustainable forestry management strategy). In this fieldtrip project, the underlying discourse is that the unsustainable exploitation of pinewood and holm-oak forestry resources by logging companies' operations may result in deforestation and abusive clearing. These factors lead to environmental and climate changes that threaten the ecosystem sustainability by contributing to loss of biodiversity and the greenhouse effect. A sustainable forestry management strategy may turn out to be the solution for sustainable exploitation of forestry resources through forest preservation and protection.

There is a widespread scholarly consensus in the traditional fieldwork literature that experiential learning in a real and practical environment is most beneficial to students. Fieldwork is thought to be a key practical strategy in geography teaching in higher education, especially in the teaching of essentially experimental areas of geographical study $[15,27,35,117-122]$. Integrating class-based knowledge and providing extended immersion in the subject are key objectives for studying in field courses [123]. Connecting various different theoretical concepts in a practical environment is deemed essential for students to become qualified geographers $[15,35]$. Direct perception of latent environmentalchange traces of evolutionary phenomena in non-pre-mediated settings [29] may stimulate the learners' cognitive processes and understanding in their attempt to figure out the underlying discourse. Direct experience, geographical enquiry, and interpretive science are three key elements for students to develop critical thinking when facing unfamiliar real-world settings "where variables cannot be tightly controlled and where arguments need to be weighed" [29].

Equally, "the residential geography fieldtrip is a key context in which geography students learn how to act and think like geography students/geographers" [124]. Even though the direct experience of acute social issues through human geography fieldtrips 
does not always challenge learners' preconceptions and attitudes [125], direct experiences of human geography fieldwork may still have a significant transformative effect on learner values and understanding [19]. Fieldwork's active, direct experience also contributes to deep learning by triggering an affective response of attentiveness [19] to others' realities and needs. All in all, despite fieldwork's limitations as a pedagogical strategy in human geography, the geography fieldtrip may still serve a dual purpose in sustainable education: as a powerful and useful learning tool on sustainable concepts and procedures, and as an empowering experience for raising awareness on landscape sustainability and fostering engaged citizenship.

Research suggests that the most common approach to the experiential learning cycle involves direct experience through fieldwork/fieldtrips and then class-based reflective observation, abstract conceptualisation, and active experimentation $[25,51,118]$. In this proposal, far from the widespread scheme of fieldtrip embedding within the learning cycle as the "concrete experience" [51], the fieldtrip is designed to complete the full learning cycle on the site visit itself. This is done by extending the interpretative experience to the application of learners' new insights to a new challenge in another setting in the landscape (another concrete experience). For instance, conclusions drawn on aquifer over-exploitation after visiting irrigation sites can be applied to a site of villa residences with on-site swimming pools. Furthermore, reflection on other practices having harmful effects on the environment may be driven after witnessing the open dumping site of solid waste near a riverbank that causes environmental degradation because of leachate filtering into the water table, with groundwater and surface water pollution. The subsequent interpretative experiences help students draw their own conclusions about linkages between the landscape landmarks, unsustainable practices, and sustainable water use and preservation. Such learning cycle completeness of a fieldtrip project during the fieldtrip itself facilitates the applicability of this fieldtrip-project design and procedure based on the four project factors to a new setting and/or environment (e.g., a Mediterranean mountain landscape).

As said before, direct experience and real outdoor settings are intrinsic features of fieldwork and fieldtrips, but completing a full experiential learning cycle during the fieldtrip experience goes beyond concrete isolated experiences. Connecting interpretive experiences and settings may be most relevant to teaching on a fieldtrip. This is even more so when the fieldtrip is approached as a holistic learning process in competence acquisition and development, where the full experiential learning cycle that takes place through direct experience in a real and practical environment further involves "participants traveling through the landscape, making additional hypotheses based on their observations and taking additional measurements (active experimentation, again) to test these hypotheses" [51].

Witnessing phenomena and associated acute issues in their real context stirs learners' sensorial and emotional domains. Their understanding through direct experience and observation may trigger cognitive mapping. Place-based analysis of every landmark connecting to the underlying thesis, which reinforces similar formal thinking abilities and cognitive processes, may contribute to the overall interpretation of the landscape. Drawing conclusions on the underlying thesis may lead to applying the learning developed to a new issue and context. By analysing the use of natural resources in a landscape, learners engage in the pursuit of optimal and feasible solutions to acute questions during the fieldtrip. Deepening awareness of harmful effects on the environment helps learners envisage the factors contributing to sustainable practices on the landscape and suggest viable measures. Making strong connections between direct interpretive experiences of diverse acute issues facing the landscape and its inhabitants in different settings (e.g., waterresource exploitation in a karstic landscape and deforestation in a Mediterranean mountain landscape) may enhance learning outcomes and have lasting impacts on students.

Second, this fieldtrip assessment proposal may be adapted to different education stages according to the learner's cognitive and skill level and physical ability. Subject adaptability involves considering the students' diversity to detect the degree of learner accessibility of field sites and locations. In previous literature, variables including physical ability, gender, 
and age were analysed to discern whether students were able-bodied for embodied fieldwork or "learning to act like and think like a geography student/geographer" (e.g., walking and climbing necessary on two physical geography fieldtrips) as a determining factor for the selection of rugged outdoor environments for fieldwork [124] (p. 272). Furthermore, increasing problems of implementation were pinpointed for self-directed research projects involving fieldwork (student numbers, less supervision availability, laboratory restrictions, semesterisation, risk assessment, etc.), even though these projects were highly valued in terms of intellectual challenge, high motivation, increased self-confidence promotion, and as a vehicle for the demonstration of a wide range of skills [126]. These potential problems are acknowledged here but are directly related to overall academic management and must be solved prior to the undertaking of fieldwork and fieldtrip projects.

Rather, it is learner needs and abilities in the field context that are at stake in effective field teaching. The present fieldtrip context embodies a socio-constructivist studentcentred self-regulating learning environment, fostering increasing geospatial autonomy in unknown settings. Students are made collaboratively responsible for their own fieldtrip project whilst reinforcing their interest in knowledge and competence building. The student may gradually develop geography competence while exploring cross-cutting competences and show a certain degree of learning autonomy. This assessment framework is learneradaptable because the assessment is based on measuring the levels of learner competence achievement. On a fieldtrip, learners may demonstrate levels of geoability and geoskill development (e.g., employing a compass or a digital tool to take a bearing for orientation and direction), as well as of social and communicative abilities (e.g., showing the ability to conduct an interview).

Third, this competence-oriented fieldtrip framework may be replicable in similar learning environments: that is, educational interventions where both disciplinary and cross-cutting competences need to be implemented in a fieldtrip, in the teaching of either geography-related specific areas of study (soil science, ecological biogeography, etc.) or other scientific fields, especially biology, environmental sciences, and geology, and in engineering teaching such as forestry and chemical engineering. Replicability of the fieldtrip project undertaken in the real context of a karstic landscape in the scientific area of chemistry involves a shift of focus onto environmental chemistry aspects. For instance, from the perspective of sustainable education, students of chemistry or environmental sciences may study the correlation between the location of chemical factories and the subsequent dumping of liquid waste and toxic chemicals into the river. Then, the students may discover sustainable and safer disposal methods for pesticides and other chemicals from industrial chemical processes while doing no harm to the environment, e.g., by the provision of disposal facility for toxic wastes and of sewage and wastewater treatment plants for purification, thereby improving river water quality.

In previous literature, key fieldwork objectives are mentioned, including teaching fundamental field skills [Hendrix, 1978], that are later broken down into intellectual skills, practical skills, practical techniques, and interests and attitudes [127]. In fact, fieldwork, is acknowledged as an active mode of learning "by doing" [23,25] and involves the development of a wide range of skills: subject-specific skills (mapping, data collection, and analysis), transferable skills (independent learning and problem-solving), and interpersonal skills $[16,128,129]$. In a particular case study of experiential learning through an integrated soil-science project, the project was aimed at developing "a wide range of student-centred approaches to learning, whilst promoting the development of a variety of transferable skills and personal qualities" [118]. This experiential learning project was implemented in four sequential steps (fieldwork, laboratory analysis, data interpretation, and preparation of a written report), thus embedding the fieldtrip as the concrete experience. Student evaluation was achieved through questionnaire analysis and group discussion, but only the written report was formally assessed.

The traditional approach to evaluation or assessment of fieldwork objectives and/or activities has been through written assignments rather than learning outcomes by skill 
development. Attention has been drawn to the difficulty of assessing fieldwork outcomes, being formulated in terms of skills developed/benefits gained, with validity in an examination context [29].

In the present framework, assessment lies along a formative continuum of incremental learning in the experiential learning cycle during the integrated fieldtrip project. This procedure allows for assessment of the whole learning process by assessing the learner's geoskills through evidence of learning outcomes, and for a different approach to fieldtrip assessment that considers learner capabilities instead of written assignments. Then, the summative assessment, whereby a student's learning (whether for knowledge, understanding, or skills) is determined at the end of a unit of work or course of study [29], may be considered at the end of the learning cycle for overall individual and teamworking performance during the fieldtrip project.

Replicability of this fieldtrip assessment framework in other areas of study must meet certain conditions: competence-oriented skills, a holistic approach to the fieldtrip project, a project question of the learner's interest and choice, and an assessment of learning outcome evidence. Skill development is fully integrated in the planning, implementation, and evaluation of the fieldtrip project as an integral part of the experiential learning cycle; thus the fieldtrip becomes a holistic teaching strategy.

These three features in this proposal and their contribution to sustainability may have a potential impact on sustainable education. The originality of the present proposal for assessing geography fieldtrips resides in the way geography and cross-cutting competences are identified and interrelated in order to formulate geoabilities and their respective geoskills that, by being developed through task performance, allow for assessing evidence of learning outcomes in a fieldtrip. Precisely, the great strength of the present proposal lies in such originality, but this is also its main weakness, to the extent that the present geography competence-oriented fieldtrip assessment framework is a theoretical proposal that has been neither repeatedly nor systematically tested in instructional practice. As a consequence, an experimental research study is needed in the future to empirically validate the results of assessing fieldtrip-applied competences and geoskills.

\section{Conclusions}

Fieldtrip through project-based learning promotes holistic education and geospatial engagement by encouraging deep learning, learner autonomy, collaborative participation, and broader applied knowledge, and also by raising awareness of landscape sustainability. The fieldtrip facilitates the development of both geography and cross-cutting competences, and helps the student enhance geoabilities and geoskills.

Both the teaching strategy and the learning method being implemented to undertake the geography fieldtrip have a direct influence on the way tasks are carried out, and consequently, on the resulting type of assessment evidence. These kinds of proactive and confident social skills are ideal for strengthening meaningful learning among peers, as are the constructivist learning environments where the students may themselves choose the landmarks, design a track, plan a route, and produce a fieldtrip discourse based on the underlying thesis, all of which are actions far from passive and relaxed attitudes.

This analysis provides a review of fieldtrip assessment and geography competences and enquiry skills. The framework offers some learning outcomes that are based on both geography competences and cross-cutting competences, as well as associated geoabilities. The geography competence-oriented fieldtrip assessment framework shows the alignment of geographical thinking linked to geospatial thinking, geography and cross-cutting competences, geoabilities, geoskills, and learning outcomes for an integral approach to fieldtrip assessment. Geospatial thinking stands out as the guiding and dominant cognitive process underpinning the competences in the fieldtrip (Table 3). The assessment framework clarifies the relationship between geoskills, tasks, and assessment evidence (Table 4). The assessment evidence may be measured by an assessment rubric that includes all learning outcomes required to produce the evidence (Table 5). 
Fieldtrips are conceived as an innovative kind of experiential learning from a holistic approach, where the full experiential learning cycle is completed during the fieldtrip experience itself. The fieldtrip is embedded into an integral project completion, whose design is determined by four factors (underlying thesis, project question, real-world settings, and sustainable solution) The fieldtrip discourse is based on the underlying thesis and articulated by the outstanding theme and landmark-related topics. The present geography competence-oriented fieldtrip assessment framework shows three strengths: applicability, adaptability, and replicability.

Funding: This research received no external funding.

Institutional Review Board Statement: Not applicable.

Informed Consent Statement: Not applicable.

Data Availability Statement: Not applicable.

Conflicts of Interest: The authors declare that the research was conducted in the absence of any commercial or financial relationships that could be construed as a potential conflict of interest.

\section{References}

1. European Union. Recommendation of the European Parliament and of the Council, of 18 December 2006, on key competences for lifelong learning. Off. J. Eur. Union 2006, 30, 2006.

2. Partoune, C.; Dewez, G.; Mérenne-Schoumaker, B. Quelles compétences terminales dans l'enseignement de la Géographie, FEGEPRO. Suppl. Feuill. d'Inf. 1998, 133, 1-24.

3. Verma, K.; Estaville, L. Role of geography courses in improving geospatial thinking of undergraduates in the United States. Int. J. Geospat. Environ. Res. 2018, 5, 3.

4. Cutter, S.L.; Golledge, R.; Graf, W.L. The big questions in geography. Prof. Geogr. 2002, 54, 305-317. [CrossRef]

5. Golledge, R.; Marsh, M.; Battersby, S. A conceptual framework for facilitating geospatial thinking. Ann. Assoc. Am. Geogr. 2008, 98, 285-308. [CrossRef]

6. United Nations. The Competences in Education for Sustainable Development; "Learning for the future: Competences in Education for Sustainable Development" ECE/CEP/AC.13/2011/6 were adopted at the sixth meeting of the United Nations Economic Commission for Europe (UNECE) Steering Committee on Education for Sustainable Development on 7 April 2011; UN: New York, NY, USA, 2011.

7. United Nations. Report of the World Commission on Environment and Development: Our Common Future; General Assembly: Annex to document A/42/427-Development and International Cooperation: Environment; UN: New York, NY, USA, 1987.

8. Meadows, M.E. Geography education for sustainable development. Geogr. Sustain. 2020, 1, 88-92. [CrossRef]

9. Goudie, A.S. The integration of human and physical geography revisited. Can. Geogr. 2017, 61, 19-27. [CrossRef]

10. Lonergan, N.; Andreson, L.W. Field-based education: Some theoretical considerations. High. Educ. Res. Dev. 1988, 7, 63-77. [CrossRef]

11. Dando, W.A.; Wiedel, J.W. A two-week field course with deferred papers: A possible solution to the problem of undergraduate fieldwork. J. Geogr. 1971, 70, 289-293. [CrossRef]

12. Gold, J.R.; Jenkins, A.; Lee, R.; Monk, J.; Riley, J.; Shepherd, I.D.H.; Unwin, D.J. Teaching Geography in Higher Education; Blackwell: Oxford, UK, 1991.

13. Haigh, M.J.; Gold, J.R. The problems with fieldwork: A group-based approach towards integrating fieldwork into the undergraduate geography curriculum. J. Geogr. High. Educ. 1993, 17, 21-32. [CrossRef]

14. Higgitt, M. Addressing the new agenda for fieldwork in higher education. J. Geogr. High. Educ. 1996, 20, 391-398. [CrossRef]

15. Kent, M.; Gilbertson, D.D.; Hunt, C. Fieldwork in geography teaching: A critical review of the literature and approaches. J. Geogr. High. Educ. 1997, 21, 313-332. [CrossRef]

16. Boyle, A.; Conchie, S.; Maguire, S.; Martin, A.; Milson, C.; Nash, R.; Rawlinson, S.; Turner, A.; Wurthmann, S. Fieldwork is good? The student experience of field courses. Planet 2003, 5, 48-51.

17. Fuller, I.C. What is the value of fieldwork? Answers from New Zealand using two contrasting undergraduate physical geography field trips. N. Z. Geogr. 2006, 62, 215-220. [CrossRef]

18. Boyle, A.; Maguire, S.; Martin, A.; Milsom, C.; Nash, R.; Rawlinson, S.; Turner, A.; Wurthmann, S.; Conchie, S. Fieldwork is good: The student perception and the affective domain. J. Geogr. High. Educ. 2007, 31, 299-317. [CrossRef]

19. Hope, M. The importance of direct experience: A philosophical defence of fieldwork in human geography. J. Geogr. High. Educ. 2009, 33, 169-182. [CrossRef]

20. Herrick, C. Lost in the field: Ensuring student learning in the 'threatened' geography fieldtrip. Area 2010, 42, 108-116. [CrossRef]

21. Stokes, A.; Magnier, K.; Weaver, R. What is the use of fieldwork? Conceptions of students and staff in geography and geology. J. Geogr. High. Educ. 2011, 35, 121-141. [CrossRef] 
22. Hammond, L. The place of fieldwork in geography education. In Debates in Geography Education; Jones, M., Lambert, D., Eds.; Routledge: Oxford, UK, 2018.

23. DeCharms, R. Motivation enhancement in educational settings. In Research on Motivation in Education; Ames, R., Ames, C., Eds.; Academic Press: Orlando, FL, USA, 1984; Volume 1, pp. 275-308.

24. Haigh, M.J. Empowerment, ethics, environmental action: A practical exercise. J. Geogr. High. Educ. 1996, 20, 399-411. [CrossRef]

25. Healey, M.; Jenkins, A. Kolb's experiential learning theory and its application in geography in higher education. J. Geogr. 2000, 99, 185-195. [CrossRef]

26. Healey, M.; Roberts, J. Engaging Students in Active Learning: Case Studies in Geography, Environment and Related Disciplines; University of Glouchestershire, Geography Discipline Network and School of Environment: Cheltenham, UK, 2004.

27. Fuller, I.; Edmondson, S.; France, D.; Higgitt, D.; Ratinen, I. International perspectives on the effectiveness of geography fieldwork for learning. J. Geogr. High. Educ. 2006, 30, 89-101. [CrossRef]

28. Dale, R.G.; Powell, R.B.; Stern, M.J.; Garst, B.A. Influence of the natural setting on environmental education outcomes. Environ. Educ. Res. 2020, 26, 613-631. [CrossRef]

29. Lambert, D.; Reiss, M. The place of fieldwork in geography and science qualifications. Geography 2016, 101, 28-34. [CrossRef]

30. Goh, K.C.; Wong, P.P. Status of fieldwork in the geography curriculum in southeast asia. In Fieldwork in Geography: Reflections, Perspectives and Actions; Gerber, R., Goh, K.C., Eds.; Kluwer: Dordrecht, The Netherlands, 2000; pp. $99-117$.

31. Biggs, J. Teaching for Quality Learning at University, 2nd ed.; Society for Research in Higher Education \& Open University Press: Buckingham, UK, 2003.

32. Bruner, J. The Process of Education; Harvard University Press: Cambridge, MA, USA, 1960.

33. Kneale, P. Organising student-centred group fieldwork and presentations. J. Geogr. High. Educ. 1996, 20, 65-74. [CrossRef]

34. García de la Vega, A. Perspectivas de futuro en el aprendizaje del paisaje. Didact. Geogr. 2019, 20, 55-77. [CrossRef]

35. Wall, G.P.; Speake, J. European geography higher education fieldwork and the skills agenda. J. Geogr. High. Educ. 2012, 36, 421-435. [CrossRef]

36. Castiglioni, B. Il paesaggio come strumento educativo. Educ. Futuro 2012, 27, 51-65.

37. Naish, M.; Rawling, E.; Hart, C. The enquiry-based approach to teaching and learning geography. In Teaching Geography in Secondary Schools: A Reader; Smith, M., Ed.; Routledge: London, UK, 2002; pp. 63-69.

38. Spronken-Smith, R.; Bullard, J.O.; Ray, W.; Roberts, C.; Keiffer, A. Where might sand dunes be on Mars? Engaging students through inquiry-based learning in geography. J. Geogr. High. Educ. 2008, 32, 71-8619. [CrossRef]

39. Roberts, M. Geographical education is powerful if ... . Teach. Geogr. 2017, 42, 6-9.

40. Krajcik, J.S.; Blumenfeld, P. Project-based learning. In The Cambridge Handbook of the Learning Sciences; Sawyer, R.K., Ed.; Cambridge University Press: New York, NY, USA, 2006.

41. Bradbeer, J. Problem-based learning and fieldwork: A better method of preparation. J. Geogr. High. Educ. 1996, 20, 11-18. [CrossRef]

42. Sproken-Smith, R. Implementing a problem-based learning approach to teaching research methods in geography. J. Geogr. High. Educ. 2005, 29, 203-221. [CrossRef]

43. García de la Vega, A. El aprendizaje basado en problemas en los itinerarios didácticos vinculados al patrimonio. Educación Futuro 2012, 27, 155-175.

44. France, D.; Haigh, M. Fieldwork@40: Fieldwork in geography higher education. J. Geogr. High. Educ. 2018, 42, 498-514. [CrossRef]

45. Hovorka, A.J.; Wolf, P.A. Activating the classroom: Geographical fieldwork as pedagogical practice. J. Geogr. High. Educ. 2009, 33, 89-102. [CrossRef]

46. Seal, W.; Mattimoe, R. The role of narrative in developing management control knowledge from fieldwork. A pragmatic constructivist perspective. Qual. Res. Account. Manag. 2016, 13, 330-349. [CrossRef]

47. Novak, J.D. A Theory of Education; Cornell University: Ithaca, NY, USA, 1977.

48. Ausubel, D.P. The Acquisition and Retention of Knowledge; Kluwer Academic Publishers: Dordrecht, The Netherlands, 2000.

49. Bruner, J.S.; Goodnow, J.J.; Austin, G.A. A Study of Thinking; John Wiley \& Sons, Inc.: New York, NY, USA, 1956.

50. Vygotsky, L.S. Mind in Society. The Development of Higher Psychological Processes; Harvard University Press: Cambridge, MA, USA, 1978.

51. Stern, M.J.; Powell, R.B. Field trips and the experiential learning cycle. J. Interpret. Res. 2020, 25, 46-50. [CrossRef]

52. McCormick, R.; James, M. Curriculum Evaluation in Schools; Croom Helm Ltd.: Kent, UK, 1983.

53. Kinder, A. Acquiring geographical knowledge and understanding through fieldwork. Teach. Geogr. 2018, 43, 109-112.

54. Kitchen, R.; Maddison, J. A fieldwork toolkit for early career geography teachers. Teach. Geogr. 2021, 46, 17-20.

55. Flinders, E. Assessing key skills through geography: A practical approach. Teach. Geogr. 2000, $25,96-98$.

56. Hopkin, J. Assessment for learning in geography. Teach. Geogr. 2000, 25, 42-43.

57. Howes, N.; Hopkin, J. Improving formative assessment in geography. Teach. Geogr. 2000, 25, 147-149.

58. Fuller, I.C.; Rawlinson, S.R.; Bevan, J.R. Evaluation of student learning experiences in physical geography fieldwork: Paddling or pedagogy? J. Geogr. High. Educ. 2000, 24, 199-215. [CrossRef]

59. Lambert, D. Using assessment to support learning. In Teaching Geography in Secondary Schools: A Reader; Smith, M., Ed.; Routledge: London, UK, 2002; pp. 123-133.

60. Krakowka, A.R. Field trips as valuable learning experiences in geography courses. J. Geogr. 2012, 111, 236-244. [CrossRef] 
61. Jo, I.; Bednarz, S.W. Evaluating geography textbook questions from a spatial perspective: Using concepts of space, tools of representation, and cognitive processes to evaluate spatiality. J. Geogr. 2009, 108, 4-13. [CrossRef]

62. Lane, R.; Bourke, T. Assessment in geography education: A systematic review. Int. Res. Geogr. Environ. Educ. 2019, 28, 22-36. [CrossRef]

63. Messick, S. The interplay of evidence and consequences in the validation of performance assessments. Educ. Res. 1994, 23, 13-23. [CrossRef]

64. Bloom, B.S.; Engelhart, M.D.; Furst, E.J.; Hill, W.H.; Krathwohl, D.R. Taxonomy of Educational Objectives: The Classification of Educational Goals. Handbook I: Cognitive Domain; David McKay: New York, NY, USA, 1956.

65. Krathwohl, D.R.; Bloom, B.S.; Masia, B.B. Taxonomy of Educational Objectives: The Classification of Educational Goals. Handbook II: The Affective Domain; David McKay: New York, NY, USA, 1964.

66. Anderson, L.W.; Krathwohl, D.R. A Taxonomy for Learning, Teaching and Assessing: A Revision of Bloom's Taxonomy of Educational Objectives: Complete Edition; Longman: New York, NY, USA, 2001.

67. Krathwohl, D.R. A revision of Bloom's taxonomy: An overview. Theory Pract. 2002, 41, 212-218. [CrossRef]

68. Dave, R.H. Psychomotor levels. In Developing and Writing Educational Objectives; Armstrong, R.J., Ed.; Educational Innovators Press: Tucson, AZ, USA, 1970; pp. 33-34.

69. Harrow, A.J. A Taxonomy of the Psychomotor Domain: A Guide for Developing Behavioral Objectives; David McKay: New York, NY, USA, 1972.

70. Biggs, J.B.; Collis, K. Evaluating the Quality of Learning: The SOLO Taxonomy; Academic Press: New York, NY, USA, 1982.

71. Biggs, J. Teaching for Quality Learning at University: What the Student Does; The Society for Research into Higher Education and Open University Press: Buckingham, UK, 1999.

72. Biggs, J. What the student does: Teaching for enhanced learning. High. Educ. Res. Dev. 1999, 18, 57-75. [CrossRef]

73. Atherton, J.S. Learning and Teaching: SOLO Taxonomy. 2005. Available online: http://www.learningandteaching.info/learning/ solo.htm (accessed on 4 November 2021).

74. Fink, D.L. A Self-Directed Guide to Designing Course for Significant Learning; Jossey-Bass: San Francisco, CA, USA, 2003.

75. Fink, L.D. Creating Significant Learning Experiences: An Integrated Approach to Designing College Courses; Jossey-Bass: San Francisco, CA, USA, 2003.

76. National Research Council. Learning to Think Spatially; National Academies Press: Washington, DC, USA, 2006.

77. Gersmehl, P. Teaching Geography; The Guilford Press: New York, NY, USA, 2008.

78. Bednarz, S.W. Setting the standard for standards: Perspectives on standard setting in the United States. Turk. J. Geogr. Educ. 2015, 1,3-9.

79. Metoyer, S.; Bednarz, S.; Bednarz, R.S. Spatial thinking in education: Concepts, development and assessment. In Geospatial Technologies and Geography Education in a Changing World; Muñiz Solari, O., Demirci, A., van der Schee, J., Eds.; Springer: Tokyo, Japan, 2015; pp. 21-34.

80. Huynh, N.T.; Solem, M.; Bednarz, S.W. A road map for learning progressions research in geography. J. Geogr. 2015, 114, 69-79. [CrossRef]

81. Bednarz, S.W.; Lee, J. What improves spatial thinking? Evidence from the Spatial Thinking Abilities Test. Int. Res. Geogr. Environ. Educ. 2019, 28, 262-280. [CrossRef]

82. García de la Vega, A. Spatial thinking acquisition througgh geospatial technologies for lifelong learning. In Geospatial Technologies in Geography Education; de Miguel, R., Donert, K., Koutsopoulos, K., Eds.; Springer: Cham, Switzerland, 2019; pp. 21-40.

83. Mérenne-Schoumaker, B. Compétences et savoirs terminaux en géographie. Réflexions et propositions. Cahiers Geogr. Québec 1999, 43, 437-449. [CrossRef]

84. Van Dijk, H.; van der Schee, J.; Trimp, H.; van der Zijpp, T. Map skills and geographical knowledge. Int. Res. Geogr. Environ. Educ. 1994, 3, 68-80. [CrossRef]

85. Gerber, R. The state of geographical education in countries around the world. Int. Res. Geogr. Environ. Educ. 2001, 10, 349-362. [CrossRef]

86. Karkdijk, J.; van der Schee, J.; Admiraal, W. Effects of teaching with mysteries on students' geographical thinking skills. Int. Res. Geogr. Environ. Educ. 2013, 22, 183-190. [CrossRef]

87. Fögele, J. Acquiring powerful thinking through geographical key concepts. In The Power of Geographical Thinking. International Perspectives on Geographical Education; Brooks, C., Butt, G., Fargher, M., Eds.; Springer: Cham, Switzerland, 2017 ; pp. 59-74.

88. Sinton, D.S.; Kolvoord, B.; Gersmehl, P.; Bednarz, S.; Uttal, D. The People's Guide to Spatial Thinking; National Council for Geographic Education: Washington, DC, USA, 2013.

89. Solem, M.; Lambert, D. Researching progress and sophistication in geography learning: Taking a critical stance. In Learning Progressions for Maps, Geospatial Technology, and Spatial Thinking: A Research Handbook; Solem, M., Huynh, N.T., Boehm, R., Eds.; National Center for Research in Geography Education: Washington, DC, USA, 2015; pp. 61-69.

90. Sinton, D.S. Spatial thinking and GIS. In Proceedings of the Workshop on Teaching Spatial Thinking from Interdisciplinary Perspectives (TSTIP 2015) at COSIT 2015 in Santa Fe, NM, USA; Burte, H., Kauppinen, T., Hegarty, M., Eds.; Cornell University: Ithaca, NY, USA, 2016. 
91. Huynh, N.T.; Sharpe, B.; Charman, C.; Tong, J.; Greensmith, I. Canada: Teaching geography through geotechnology across a decentralized curriculum landscape. In International Perspectives on Teaching and Learning with GIS in Secondary Schools; Milson, A.J., Demirci, A., Kerski, J.J., Eds.; Springer: New York, NY, USA, 2012; pp. 37-47.

92. Ishikawa, T. Geospatial thinking and spatial ability: An empirical examination of knowledge and reasoning in geographical science. Prof. Geogr. 2013, 65, 636-646. [CrossRef]

93. Lane, R.; Carter, J.; Bourke, T. Concepts, Conceptualization, and Conceptions in Geography. J. Geogr. 2018, 11-20. [CrossRef]

94. Solem, M.; Cheung, I.; Schlemper, M.B. Skills in professional geography: An assessment of workforce needs and expectations. Prof. Geogr. 2008, 60, 356-373. [CrossRef]

95. Metoyer, S.; Bednarz, R. Spatial thinking assists geographic thinking: Evidence from a study exploring the effects of geospatial technology. J. Geogr. 2017, 116, 20-33. [CrossRef]

96. Wing, J.M. Computational thinking. Commun. Assoc. Comput. Mach. 2006, 49, 33-35. [CrossRef]

97. Andrews, A.C. The analogy theme in geography. J. Geogr. 1987, 86, 194-198. [CrossRef]

98. Holyoak, K.J.; Thagard, P. Analogical mapping by constraint satisfaction. Cogn. Sci. 1989, 13, 295-355. [CrossRef]

99. Lee, J.; Harm, K.R. The use of analogy in teaching and learning geography. J. Korean Geogr. Soc. 2011, 46, 534-554.

100. Holyoak, K.J.; Thagard, P. The analogical mind. Am. Psychol. 1997, 52, 35-44. [CrossRef] [PubMed]

101. Nussbaum, M. Education and democratic citizenship: Capabilities and quality education. J. Hum. Dev. 2006, 7, 385-395. [CrossRef]

102. Roegiers, X. Un Cadre Conceptuel pour l'Évaluation des Compétences; UNESCO: Paris, France, 2016.

103. Bruner, J. Life as narrative. Soc. Res. 2004, 71, 691-710.

104. Dummer, T.J.B.; Cook, I.G.; Parker, S.L.; Barret, G.A.; Hull, A.P. Promoting and assessing 'deep learning' in geography fieldwork. An evaluation of reflective fieldwork diaries. J. Geogr. High. Educ. 2008, 32, 459-479. [CrossRef]

105. Cortazzi, M. Primary Teaching How It Is. A Narrative Account; David Fulton Publishers: London, UK, 1991.

106. Cortazzi, M. Narrative Analysis; The Falmer Press: London, UK, 1993.

107. Adams, P.C.; Jansson, A. Communication geography: A bridge between disciplines. Commun. Theory 2012, 22, 299-318. [CrossRef]

108. Healey, R.L. The power of debate: Reflections on the potential of debates for engaging students in critical thinking about controversial geographical topics. J. Geogr. High. Educ. 2012, 36, 239-257. [CrossRef]

109. Bednarz, S.W. Geographic information systems: A tool to support geography and environmental education? GeoJournal 2004, 60, 191-199.

110. Huynh, N.; Gotwals, A. What are learning progressions? In Learning Progressions for Maps, Geospatial Technology, and Spatial Thinking: A Research Handbook; Solem, M., Huynh, N.T., Boehm, R., Eds.; Association of American Geographers: Washington, DC, USA, 2014; pp. 1-8.

111. Gryl, I.; Jekel, T.; Donert, K. GI and spatial citizenship. In Learning with Geoinformation V—Lernen mit Geoinformation V; Jekel, T., Koller, A., Donert, K., Vogler, R., Eds.; Wichmann: Berlin, Germany, 2010; pp. 2-11.

112. Shin, E.E.; Bednarz, S.W. Spatial Citizenship Education Citizenship through Geography; Routledge: New York, NY, USA, 2019.

113. Uhlenwinkel, A. Geographical thinking: Is it a limitation or powerful thinking? In The Power of Geographical Thinking. International Perspectives on Geographical Education; Brooks, C., Butt, G., Fargher, M., Eds.; Springer: Cham, Switzerland, 2017 ; pp. 41-53.

114. Pearce, D.; Markandya, A.; Barbier, E. Blueprint for a Green Economy; Earthscan Publications: London, UK, 1996.

115. Floberg, K. Best Practices in Environmental Education Fields Trips: The Importance of Curricular Integration, Preparation, and Follow-Up; University of Minnesota: Minneapolis, MN, USA, 2015.

116. Europpean Commission. Proposal for a Council Recommendation on Key Competences for LifeLong Learning; Europpean Commission: Brussels, Belgium, 2018.

117. Moles, R. Biogeographical field study of farmland. J. Geogr. High. Educ. 1977, 1, 20-26. [CrossRef]

118. Mellor, A. Experiential learning through integrated project work: An example from soil science. J. Geogr. High. Educ. 1991, 15, 135-149. [CrossRef]

119. Clarke, D. The changing national context of fieldwork in geography. J. Geogr. High. Educ. 1996, 23, 385-398. [CrossRef]

120. McEwen, L. Fieldwork in the undergraduate geography programme: Challenges and changes. J. Geogr. High. Educ. 1996, 20, 379-384. [CrossRef]

121. Scott, I.; Fuller, I.C.; Gaskin, S. Life without fieldwork: Some lecturers' perceptions of geography and environmental science fieldwork. J. Geogr. High. Educ. 2006, 30, 161-171. [CrossRef]

122. Fuller, I.C. Taking students outdoors to learn in high places. Area 2011, 44, 7-13. [CrossRef]

123. Hendrix, T.E. An assessment of field courses in geology. J. Geol. Educ. 1978, 26, 160-164. [CrossRef]

124. Nairn, K. Embodied fieldwork. J. Geogr. 1999, 98, 272-282. [CrossRef]

125. Nairn, K. The problems of utilizing 'direct experience' in geography education. J. Geogr. High. Educ. 2005, 29, 293-309. [CrossRef]

126. Tinsley, H.M. Training undergraduates for self-directed field research projects in physical geography: Problems and possible solutions. J. Geogr. High. Educ. 1996, 20, 55-64. [CrossRef]

127. Thompson, D.B. On discerning the purposes of geological fieldwork. Geol. Teach. 1982, 7, 59-65.

128. Andrews, J.; Kneale, P.; Sognez, W.; Stewart, M.; Stott, T. Carrying out pedagogic research into the constructive alignment of fieldwork. Planet 2003, 5, 51-52.

129. Shah, A.; Treby, E. Using a community based project to link teaching and research: The Bourne Stream Partnership. J. Geogr. High. Educ. 2006, 30, 33-48. [CrossRef] 